\title{
Tracing hepatitis B virus (HBV) genotype B5 (formerly B6) evolutionary history in the circumpolar Arctic through phylogeographic modelling
}

\author{
Remco Bouckaert $^{1}$ ， Brenna C. Simons ${ }^{2}$, Henrik Krarup ${ }^{3}$ ， T. Max Friesen ${ }^{4}$, Carla Osiowy ${ }^{\text {Corresp. } 5,6}$ \\ 1 Department of Computer Science, University of Auckland, Auckland, New Zealand \\ Alaska Native Tribal Health Consortium, Anchorage, Alaska, United States of America \\ 3 Section of Molecular Diagnostics, Clinical Biochemistry, Aalborg University Hospital, Aalborg, Denmark \\ 4 Department of Anthropology, University of Toronto, Toronto, Ontario, Canada \\ 5 National Microbiology Laboratory, Public Health Agency of Canada, Winnipeg, Manitoba, Canada \\ 6 Department of Medical Microbiology and Infectious Diseases, University of Manitoba, Winnipeg, Manitoba, Canada \\ Corresponding Author: Carla Osiowy \\ Email address: carla.osiowy@phac-aspc.gc.ca
}

Background. Indigenous populations of the circumpolar Arctic are considered to be endemically infected ( $>2 \%$ prevalence) with hepatitis B virus (HBV), with subgenotype B5 (formerly B6) unique to these populations. The distinctive properties of HBV/B5, including high nucleotide diversity yet no significant liver disease, suggest virus adaptation through long-term host-pathogen association.

Methods. To investigate the origin and evolutionary spread of HBV/B5 into the circumpolar Arctic, fiftyseven partial and full genome sequences from Alaska, Canada and Greenland, having known location and sampling dates spanning 40 years, were phylogeographically investigated by Bayesian analysis (BEAST 2 ) using a reversible-jump-based substitution model and a clock rate estimated at $4.1 \times 10^{-5}$ substitutions/site/year.

Results. Following an initial divergence from an Asian viral ancestor approximately 1954 years before present (YBP; 95\% highest probability density interval [1188, 2901]), HBV/B5 coalescence occurred almost 1000 years later. Surprisingly, the HBV/B5 ancestor appears to locate first to Greenland in a rapid coastal route progression based on the landscape aware geographic model, with subsequent B5 evolution and spread westward. Bayesian skyline plot analysis demonstrated an HBV/B5 population expansion occurring approximately 400 YBP, coinciding with the disruption of the Neo-Eskimo Thule culture into more heterogeneous and regionally distinct Inuit populations throughout the North American Arctic.

Discussion. HBV/B5 origin and spread appears to occur coincident with the movement of Neo-Eskimo (Inuit) populations within the past 1000 years, further supporting the hypothesis of HBV/host coexpansion, and illustrating the concept of host-pathogen adaptation and balance. 
1

3

4

6

7

8

$9{ }^{1}$ Department of Computer Science, University of Auckland, Auckland, New Zealand; ${ }^{2}$ Alaska Canada

\section{Tracing hepatitis B virus (HBV) genotype B5 (formerly B6) evolutionary} history in the circumpolar Arctic through phylogeographic modelling

\section{Remco Bouckaert ${ }^{1}$, Brenna C. Simons², Henrik Krarup ${ }^{3}$, T. Max Friesen ${ }^{4}$, and Carla}

\section{Osiowy $* 5,6$}

7

(1)

Native Tribal Health Consortium, Anchorage, Alaska, USA; ${ }^{3}$ Section of Molecular Diagnostics, Clinical Biochemistry, Aalborg University Hospital, Aalborg, Denmark; ${ }^{4}$ Department of Anthropology, University of Toronto, Toronto, Ontario, Canada; ${ }^{5}$ National Microbiology Laboratory, Public Health Agency of Canada, Winnipeg, Manitoba, Canada; ${ }^{6}$ Department of Medical Microbiology and Infectious Diseases, University of Manitoba, Winnipeg, Manitoba,

*Corresponding author:

21 Name: Carla Osiowy

22 e-mail: $\quad$ carla.osiowy@phac-aspc.gc.ca 


\section{Abstract}

24 Background. Indigenous populations of the circumpolar Arctic are considered to be endemically

25 infected ( $>2 \%$ prevalence) with hepatitis B virus (HBV), with subgenotype B5 (formerly B6)

26 unique to these populations. The distinctive properties of HBV/B5, including high nucleotide

27 diversity yet no significant liver disease, suggest virus adaptation through long-term host-

28 pathogen association.

29 Methods. To investigate the origin and evolutionary spread of HBV/B5 into the circumpolar

30 Arctic, fifty-seven partial and full genome sequences from Alaska, Canada and Greenland,

31 having known location and sampling dates spanning 40 years, were phylogeographically

32 investigated by Bayesian analysis (BEAST 2) using a reversible-jump-based substitution model

33 and a clock rate estimated at $4.1 \times 10^{-5}$ substitutions/site/year.

34 Results. Following an initial divergence from an Asian viral ancestor approximately 1954 years

35 before present (YBP; 95\% highest probability density interval [1188, 2901]), HBV/B5

36 coalescence occurred almost 1000 years later. Surprisingly, the HBV/B5 ancestor appears to

37 locate first to Greenland in a rapid coastal route progression based on the landscape aware

38 geographic model, with subsequent B5 evolution and spread westward. Bayesian skyline plot

39 analysis demonstrated an HBV/B5 population expansion occurring approximately $400 \mathrm{YBP}$,

40 coinciding with the disruption of the Neo-Eskimo Thule culture into more heterogeneous and

41 regionally distinct Inuit populations throughout the North American Arctic.

42 Discussion. HBV/B5 origin and spread appears to occur coincident with the movement of Neo-

43 Eskimo (Inuit) populations within the past 1000 years, further supporting the hypothesis of

$44 \mathrm{HBV} /$ host co-expansion, and illustrating the concept of host-pathogen adaptation and balance. 


\section{Introduction}

46

47 Endemic infection ( $>2 \%$ ) with hepatitis B virus (HBV) has been historically observed throughout 48

Inuit and Alaska Native populations of the western circumpolar Arctic (McMahon, 2004; Minuk

\& Uhanova, 2003; Tulisov et al., 2007), although ongoing vaccination programs, starting in the mid-1980's to mid-1990's, have or are expected to reduce prevalence to non-endemic levels (Huynh et al., 2014; McMahon et al., 2011). Studies have shown several HBV genotypes circulating within Inuit or Alaska Native people of the circumpolar Arctic; however, subgenotype B5 (HBV/B5; formerly B6 (Kramvis, 2014)) is unique to this population and has not been found elsewhere (Osiowy, Simons \& Rempel, 2013). While chronic HBV infection often results in liver cirrhosis or hepatocellular carcinoma, HBV/B5 chronic infection is infrequently associated with serious adverse effects (Krarup et al., 2008; Minuk et al., 2013; Sakamoto et al., 2007) and rather, results in a 'benign' outcome. This clinical association, together with the distinct nucleotide diversity and mutation rate observed with HBV/B5 compared to other HBV genotypes infecting Inuit and Alaska Native populations (Kowalec et al., 2013), suggests potential pathogen attenuation within the population due to host-pathogen co-evolution (Paraskevis et al., 2013; Tedder et al., 2013). There is support for human/HBV coevolution (Paraskevis et al., 2013; Suh et al., 2013), particularly with respect to the distinct geographic distribution of genotypes observed throughout the world and association with specific ethnic groups. In particular HBV genotypes associated with remote or isolated indigenous populations provide a more stable foundation to investigate the coevolving relationship based on the historical HBV endemicity within these populations and their status as the first peoples of a geographic region (Littlejohn, Locarnini \& Yuen, 2016; Zehender et al., 2014). In order to investigate the origin, evolution and spread of HBV/B5, spatial and temporal 
69 phylogenetic analysis of HBV sequences obtained throughout the circumpolar Arctic was

70 performed. This analysis should further our understanding of the natural history, origin and

71 evolutionary rate of $\mathrm{HBV} / \mathrm{B} 5$, which in turn provides increased understanding of $\mathrm{HBV}$

72 evolutionary history and the concept of host-pathogen balance through co-evolution. Through

73 incorporation of viral population size and evolutionary rate estimates, the virus strain could be

74 traced through the circumpolar region to infer the time to the most recent common ancestor

75 (tMRCA) and putative dispersal over time to support long-term association of HBV/B5 with

76 populations indigenous to the western circumpolar region.

77

Materials and Methods

79

Serum samples, HBV DNA extraction and sequencing analysis

81

82 Twenty-two serum samples from various locations in Nunavut were collected from HBV/B5-

83 infected individuals having self-identified as Inuit. All specimens were described previously in

84 studies for which informed patient consent was obtained for HBV molecular analysis and study

85 approval was granted from institutional ethics review boards (Health Canada/Public Health

86 Agency of Canada research ethics board protocol number REB-2006-0048 and REB-2012-0062;

87 University of Manitoba research ethics board approval number HS15821; (Huynh et al., 2014;

88 Larke et al., 1987; Minuk et al., 2013; Osiowy, Larke \& Giles, 2011)). HBV DNA was extracted

89 from $200 \mu \mathrm{l}$ sera by SDS-proteinase K lysis and phenol chloroform extraction methods (Osiowy,

90 2002) and resuspended in $30 \mu 1$ sterile, nuclease-free water. Amplification of the full HBV

91 genome was performed using a high fidelity polymerase (Roche Expand High Fidelity ${ }^{\text {Plus }}$

92 System, Roche Diagnostics, Laval, QC, Canada) as described previously (Osiowy et al., 2010). 
93 Samples having an HBV viral load precluding full genome amplification and sequencing were

94 partially sequenced using primers and methods described previously (Minuk et al., 2012).

95 Specific amplicons were gel-purified prior to cycle sequencing with an AB 3730 XL DNA

96 Analyzer using Big Dye 3.1 terminator chemistry (Thermo Fisher Scientific, Burlington, ON,

97 Canada). Sequences were assembled and analysed using DNA sequence analysis software

98 (Lasergene software suite v 10.0, DNASTAR, Madison, WI, USA). Sequences were submitted to

99 GenBank under accession numbers KP659234-KP659255. Nine other sequences previously

100 described from individuals residing in Nunavut were included (JN792894, JN792896, JN792897,

101 JN792900, JN792901, DQ463795, DQ463796, DQ463799, DQ463802; (Kowalec et al., 2013;

102 Osiowy et al., 2006)). Thus a total of 31 partial and full genome HBV sequences from Nunavut

103 were included in the analysis (Table 1).

104

105 Ten serum samples from various locations in Alaska were collected and the HBV DNA extracted 106 and sequenced as described for Nunavut specimens. Participants were enrolled statewide by the 107 Liver Disease and Hepatitis Program at the Alaska Native Tribal Health Consortium (Anchorage, 108 AK). This study was approved by the Alaska Area (Indian Health Service) and the Centers for

109 Disease Control and Prevention Institutional Review Boards (Protocol number AAIRB 2001-07-

110 022/1996-01-001). The study and manuscript were approved by the Alaska Native Tribal Health

111 Consortium and the Southcentral Foundation Board of Directors. All participants provided

112 written informed consent. Sequences were submitted to GenBank under accession numbers

113 KP659219-KP659228. Six other sequences previously described from individuals residing in

114 Alaska were included (AB287314 - AB297319; (Sakamoto et al., 2007)). Thus a total of 16

115 partial and full genome HBV sequences from Alaska were included in the analysis (Table 1). 
117 Four serum specimens collected from East Greenland were extracted for HBV DNA and

118 sequenced as described for Nunavut specimens. These specimens were collected previously for

119 the study by Krarup, et al. (2008), in which ethics approval was granted by the Commission for

120 Scientific Research in Greenland (Approval number 505-99), and written informed consent was

121 obtained from each participant. Sequences were submitted to GenBank under accession numbers

122 KP659230-KP659233. Six other sequences previously described from individuals located in

123 West Greenland were included (AB287320 - AB287325; (Sakamoto et al., 2007)). Thus a total

124 of 10 partial and full genome HBV sequences from Greenland were included in the analysis

125 (Table 1).

126

127 Methods for specimen and data collection and analysis were carried out in accordance with the

128 Tri-Council Policy on Ethical Conduct for Research Involving Humans (Canadian Institutes of

129 Health Research, Natural Sciences and Engineering Research Council of Canada, and the Social

130 Sciences and Humanities Research Council of Canada).

131

132 Phylogenetic analysis and evolutionary dynamics

133

134 All sequences listed in Table 1, including partial and full genome sequences, were aligned using 135 ClustalX (Thompson et al., 1997), resulting in an alignment with 3220 sites. Bayesian analysis 136 was performed using Markov Chain Monte Carlo (MCMC) methods implemented in BEAST 2 137 (Bouckaert et al., 2014) for the phylogeny and estimation of the HBV effective population size. 138 In order to facilitate convergence, the MCMC chains were run sufficiently long; at 40 million 
139 generations with sampling every 10000 steps and the first $10 \%$ of samples discarded as burn-in.

140 During analysis, the sequences in the West Greenland clade were restricted to be monophyletic.

141 Without monophyly constraint the analysis did not converge, and from our experience,

142 sequences from the western circumpolar regions of Alaska, Canada and Greenland, tend to

143 cluster into monophyletic clades (Kowalec et al., 2013; Sakamoto et al., 2007). A coalescent tree

144 prior was chosen due to the intra-species analysis and the assumption that sampling across all

145 clades was consistent and accurate. The XML file including all data for BEAST 2 analysis is

146 available as supplemental information (Data S1).

147

148 The aligned sequence data consisting of full length and partial sequence was partitioned into 149 eight parts consisting of sites 1-835, 836-1373, 1374-1620, 1621-1900, 1901-2307, 2308-2450, 150 2451-2847, and 2848-3220, based on gene boundaries in the genome. Since each of these 151 partitions code for different genes, and some even two genes in different reading frames, these 152 partitions will be governed by different evolutionary mechanisms. Therefore, a separate 153 substitution model was used with each partition having its own relative substitution rate. We 154 used the reversible-jump-based substitution model (Bouckaert, Alvarado-Mora \& Pinho, 2013) 155 with four gamma categories and invariant sites so that uncertainty in the substitution model 156 choice is integrated out. This model jumps between the models F81 (Felsenstein, 1981), HKY85 157 (Hasegawa, Kishino \& Yano, 1985), TAN93 (Tamura \& Nei, 1993), TIM (Posada, 2003), EVS

158 (Drummond \& Bouckaert, 2015) and GTR (Tavaré, 1986) and automatically estimates the model 159 parameters during the MCMC.

160 
161 The phylogenetic tree was prepared using DensiTree implemented in BEAST 2, which has the

162 advantage of being able to visualize the uncertainty in both node heights and topology, such that

163 a qualitative analysis of all tree sets can be made (Heled \& Bouckaert, 2013). Bayesian skyline

164 plot analysis was used to estimate the relative HBV/B5 population size through time (Drummond

165 et al., 2005). A coalescent tree prior is used, which is an appropriate prior for within species

166 samples. Furthermore, it uses a non-parametric population function, so there is no commitment

167 to a parametric population function; that is, a population history, such as an exponentially

168 growing population or constant population, is not assumed beforehand. Default settings for the

169 Bayesian skyline plot (five intervals, default hyper priors) were used.

170

171 Geographic analysis

172

173 A joint geographic and phylogenetic analysis of aligned partial and full genome sequences listed

174 in Table 1 using the landscape aware geographic model (Bouckaert et al., 2012) was performed

175 using BEAST 2. Essentially, the model uses a random walk based on successive steps in a

176 random direction to model the spread of organisms across a landscape. The area of interest

177 throughout the western circumpolar Arctic region that is being investigated contains many large

178 landmasses among long stretches of coastline. The landscape aware model was configured to

179 distinguish between sea, inland, and coastal regions and assumed fast (10-fold higher) dispersion

180 rates along the coast compared to dispersion rates inland. Furthermore, there is a reluctance to

181 get into water, but once in water, the rate of dispersal is very high (10-fold higher than along the 182 coast).

183 
184 A prior on the location of the root of the HBV phylogeographic summary tree was used to

185 enforce its location on the Asian side of the Bering Strait, in order to minimize the geographical

186 area used for the landscape aware model, and to parallel the likely HBV/B5 origin and dispersal

187 from Asia through the Bering Strait region (Paraskevis et al., 2015); thus, the Asian HBV

188 sequences do not impact the geography of the North American and Greenlandic HBV sequences.

189

190 During the MCMC run, locations of internal nodes are sampled. To position a branch onto the

191 map, the sample location information is used for the start and end of a branch. To find the

192 location of the mid-point of the branch of length $t$, the location in a $32 \times 32$ grid that maximises

193 the probability of going from a start location to that grid point after time $t / 2$, multiplied by the

194 probability of going from an end location to that grid point after time $t / 2$, is determined. The

195 branch is continually split recursively until all intermediate locations are neighbouring grid

196 points. This determines the most probable path for a branch, which can then be visualised by

197 straight lines connecting grid points. Note that Bayesian analyses do not produce single summary

198 trees (visualised as a blue solid line) but distributions over trees are represented. These are

199 samples from the posterior in the form of a set of trees. Each of these trees follows a somewhat

200 different trajectory and can be visualised individually to get an impression of the uncertainty in

201 the distribution route as well as the area that potentially was visited. Instead of drawing each tree

202 using an opaque line (as was done for the summary tree) a colored dot is drawn using

203 translucency for every grid point in the $32 \times 32$ grid traversed by the trajectory associated with the

204 tree. Time depth can be visualised using colour, ranging from light blue (older) to red (younger).

205

206

207

208

\section{Results}




\section{HBV/B5 phylogenetic analysis}

210

211 A total of $72 \mathrm{HBV}$ sequences were included in the phylogenetic analysis; fifty-seven HBV/B5

212 sequences, of which 40 were full genome sequence, and $11 \mathrm{HBV} / \mathrm{B} 1$ and $4 \mathrm{HBV} / \mathrm{B} 2 \mathrm{GenBank-}$

213 derived full genome sequences used as an outgroup (Table 1). HBV/B1 and B2 sequences were

214 included in the phylogenetic analysis to delineate the ancestral foundation and putative

215 geographic origin of $\mathrm{HBV} / \mathrm{B} 5$, as $\mathrm{HBV} / \mathrm{B} 1$ sequences are most phylogenetically similar to

$216 \mathrm{HBV} / \mathrm{B} 5$ sequences, while HBV/B2 sequences are more distantly related to both B1 and B5

217 (Sakamoto et al., 2007). Both HBV/B1 and B2 are localized to regions in Asia (Sakamoto et al.,

218 2007) but have not been observed to circulate in Arctic regions. Location information, sample

219 dates and the presence of the precore stop codon mutation (G1896A) for all sequences are listed

220 in Table 1, as are the genomic regions covered for partial sequences. Due to privacy concerns

221 given the small population sizes of the Inuit communities, detailed location information is not

222 given for certain samples not previously described.

223

224 Figure 1 shows the relative substitution rates and preferred substitution models for the

225 partitioned data following reversible-jump-based substitution model analysis. Since HBV has a

226 complex genome with many overlapping open reading frames, partitioning can be expected to

227 give a more realistic model of substitution, as each subgenomic region has a different

228 substitution rate (Bouckaert, Alvarado-Mora \& Pinho, 2013). The resulting general trends are

229 similar to earlier findings of Bouckaert, Alvarado-Mora \& Pinho (2013), such as the requirement

230 for complex substitution models in sequence areas where genes overlap, and higher rates where

231 there is no overlap. 
233 The uncorrelated log-normal relaxed clock (Drummond et al., 2006) fit the data better than the

234 strict clock, as resulting likelihoods and posterior were non-overlapping. Furthermore, the mean

235 coefficient of correlation of 0.63 (95\% highest probability density (HPD) Interval $[0.52,0.75])$

236 suggests that the strict clock could be dismissed. The clock was calibrated using archeological

237 evidence from human history, and since humans are the only host for HBV in Arctic regions we

238 can assume they share the same history. Archaeological evidence relevant to a rapid Inuit (Neo-

239 Eskimo) migration to the Eastern Arctic from regions of Alaska starting approximately 900 to

240700 YBP (sigma=50 year; (Friesen \& Arnold, 2008; McGhee, 2000; Raghavan et al., 2014)) was

241 used to calibrate the root of genotype B coalescence, with an external calibrator estimate of 647

242 to 953 YBP. This migration displaced earlier Dorset Paleo-Inuit peoples with very little evidence

243 for genetic or cultural interaction between the two populations (Raghavan et al., 2014), thus

244 representing a re-setting of the human population distribution in the Eastern Arctic. Based on the

245 mean external calibrator results, the HBV evolutionary clock rate for this study was estimated at

$2464.1 \times 10^{-5}$ substitutions per site per year (95\% HPD interval $\left.\left[3.1 \times 10^{-5}, 5.1 \times 10^{-5}\right]\right)$, which is in

247 keeping with median rates from most literature sources, and takes into account the faster rate

248 noted for sequences from HBeAg negative individuals (Harrison et al., 2011), of which most

$249 \mathrm{HBV} / \mathrm{B} 5$-infected individuals were in the present study due to a high prevalence of the precore

250 stop codon mutation A1896 (Table 1; (Osiowy, Larke \& Giles, 2011)). The estimated clock rate

251 gave a root height for genotype B5 of 902 YBP (95\% HPD Interval [803-1001]) following

252 DensiTree visualization of the posterior distribution over the set of trees (Fig. 2). This dating is

253 consistent with minimum tMRCA estimates in the literature for genotype B5 (Paraskevis et al.,

2542015 ) and corresponds to the external calibrator employed. The DensiTree topology was found 
255 to be well resolved with approximately two thirds of the clades having over 95\% posterior 256 support.

257

258 Unexpectedly, the estimated dates derived for the MRCA for HBV/B5 geographic lineages 259 appear to shift in an east to west fashion, such that the tMRCA for the Greenlandic HBV/B5 260 node is approximately 650 YBP, while the average tMRCA for the Canadian and Alaskan $261 \mathrm{HBV} / \mathrm{B} 5$ nodes is approximately 590 YBP. The earlier Greenlandic B5 branch is well supported 262 by an $88.7 \%$ probability, while there is uncertainty as to whether subsequent branching is 263 between Nunavut (east and west) and Alaska B5 taxa (47.2\% probability) or between east 264 Nunavut and Alaska/west Nunavut B5 (27.1\% probability). This demonstrates that the root of $265 \mathrm{HBV} / \mathrm{B} 5$ is associated with Greenlandic HBV genomic sequences, thus suggesting phylogenetic 266 evolution of the virus during westward dispersal back into Alaska (Fig. 2).

267

268

HBV/B5 population history and dispersal in the western circumpolar Arctic

269

270 Figure 3 shows the estimated effective number of HBV infections over time, where the y-axis

271 represents the effective population size of HBV. A rapid expansion of the viral population is

272 estimated to have occurred from approximately $400 \mathrm{YBP}$, which coincides with a rapid

273 diversification shown in Fig. 2 within the same time frame. This coincides with archaeological

274 evidence for a period of transformation in precontact Arctic society, during which a previously

275 relatively homogeneous Thule society transformed into modern Inuit, starting approximately 500

276 YBP and continuing onwards for several centuries. This transformation is associated with

277 population migrations, environmental shifts, and contact with Europeans (Finkelstein, Ross \& 
278 Adams, 2009; Friesen, 2010; McGhee, 1994). An estimate of the current HBV/B5 population

279 size in the order of 100,000 is consistent with current estimated host population size estimates

280 based on population statistics (Central Intelligence Agency, 2015; Statistics Canada, 2014;

281 United States Census Bureau, 2012), in keeping with each infected person hosting an entire HBV

282 quasi-species population (Lauring \& Andino, 2010). If the molecular clock rate is increased, this

283 results in reduced population size estimates; thus, confidence in the rate used is provided by the

284 current estimates being consistent with current host populations (Drummond \& Bouckaert,

285 2015). Coincident timing of the HBV population expansion with historical events provides

286 further confidence in the clock rate employed.

287

288 The posterior distribution over the HBV/B5 tree sets is shown in Fig. 4 projected onto the map of 289 the western circumpolar Arctic region as a function of increasing time. An animation of the 290 landscape aware geographic model analysis which demonstrates the entire dispersal estimation 291 over time and from which Fig. 4 is taken is provided as a supplemental file (Video S1). The blue 292 line in Fig. 4 represents the path of the maximum clade confidence tree, shown in Fig. 2, and the 293 set of trees representing the posterior is projected onto the map as transparent coloured dots 294 indicating uncertainty in the path of dispersal, especially over northern Nunavut island regions.

295 Thus, the model assumes that HBV/B5 follows a "random walk" through a geographic area, but 296 it does not infer the nature of the host population; i.e., it is neither assumed that the walk occurs 297 through empty space nor populated space, but the virus distribution may approximate the 298 associated (uninfected) host population. The summary tree has good posterior support for most 299 clades (about two third of the clades in the summary tree have over 95\% posterior support), 300 except those lower in the tree in Alaska and Nunavut, and there was a clear, monophyletic 
301 separation of geographic HBV sequence clades, with $88.7 \%$ and $100 \%$ posterior support for the

302 Alaska/Nunavut and Greenland/Nunavut/Alaska clades, respectively.

303

304 The advantage of the landscape aware model is that it allows features of the landscape, such as

305 water, coastlines and inland areas, to be treated as having different dispersal rates. Original

306 dispersal of $\mathrm{HBV} / \mathrm{B} 5$ is estimated to have been more rapid along geographic coastal routes

307 (Helgason et al., 2006; Maxwell, 1985; Morrison, 1999), similar to what has been described for

308 HBV genotype C (Littlejohn, Locarnini \& Yuen, 2016). The result of the landscape aware

309 geographic model analysis suggests a rapid evolution of the HBV/B5 ancestor and spread along

310 geographic coastal routes following its introduction into the Eastern Arctic from Alaska via Asia.

311 As virus spread along the coast is estimated to be more rapid than inland, modelling tends to

312 bend long branches along the coast, such as the branch from Asia into Alaska and further

313 eastward. The modelling reconstruction shows Greenlandic viral evolution transpiring via the

314 northern islands of Nunavut. The uncertainty of the actual dispersal into Greenland is shown by

315 the maximum clade confidence tree vs. the posterior distribution (green dots in panel C of Fig. 4)

316 throughout Ellesmere Island. This uncertainty is likely due to the lack of HBV sequence

317 coverage in the data set from the more northern regions of Nunavut. However, despite this

318 limitation, the resulting analysis provides strong statistical support for an early dispersal route to

319 Greenland through Ellesmere Island. Note the evident walk back towards Alaska in Fig. 4B and 320 C.

321

\section{Discussion}

323 
324 Our analysis of HBV/B5 sequences from the western circumpolar Arctic suggests that the virus

325 evolved within Asia approximately 2000 YBP, with a later introduction into the Arctic. The

326 eventual spread of the virus throughout the region possibly coincided with a sudden increase in

327 the effective population of $\mathrm{HBV}$, during the period of Thule Inuit transformation associated with

328 expanded trade interactions and migrations of previously settled populations, creating a

329 population of naïve hosts. Visualisation of phylogeographic analysis suggests that an initial

330 rapid location of the virus to Greenland via Arctic coastal regions was followed by expansion

331 and eventual HBV/B5 spread and evolution in a westward fashion, back to Alaska. A previous

332 study investigating the origins of HBV also used a "coastal trail" model to explain the

333 distribution of HBV genotype $\mathrm{C}$ throughout indigenous and relict populations of the Asia-Pacific

334 region (Littlejohn, Locarnini \& Yuen, 2016).

335

336 Established HBV subgenotypes have been located to East Asia at least $3000 \mathrm{YBP}$, based on

337 phylogenetic analysis of HBV genotype $\mathrm{C} 2$ genomic sequences isolated from a $16^{\text {th }}$ century

338 Korean mummy (Bar-Gal et al., 2012). Furthermore, cladogenesis of the major HBV lineages

339 and genotypes is estimated to have occurred approximately 20,000 YBP, due to major human

340 population migrations (Paraskevis et al., 2013). The tMRCA for genotype B is estimated to have

341 occurred anywhere from approximately 12 to 19.7 thousand YBP, depending on the clock model

342 used (Paraskevis et al., 2013; Paraskevis et al., 2015). The use of external versus internal

343 calibration approaches will influence phylodynamic reconstructions (Zehender et al., 2014).

344 Thus, the use of a slower substitution rate $\left(5 \times 10^{-5}\right.$ to $\left.<1 \times 10^{-6}\right)$ together with a calibration based

345 on ancient events, such as fossil or human migration data, results in older ancestral nodes, which

346 appears to support the hypothesis of HBV/human host co-expansion (Paraskevis et al., 2015) as a 
347 model of HBV origin. An external or remote calibration approach is appropriate for the present

348 study as genotype B5 is uniquely isolated within western circumpolar Arctic indigenous

349 populations and associations between HBV/B5 molecular and clinical outcome characteristics

350 suggest a long-term history of the virus within this particular population (Kowalec et al., 2013;

351 Sakamoto et al., 2007). As most HBV/B5 is associated with HBeAg negativity (Osiowy, Larke

$352 \&$ Giles, 2011), the clock rate is expected to be somewhat faster than is observed with $\mathrm{HBeAg}$

353 positive individuals (Harrison et al., 2011).

354

355 The clock rate estimated in the present analysis results in the most recent common ancestor of

356 HBV subgenotypes B1, B2 and B5 to be present approximately 2000 YBP. Assuming this rate is

357 correct; the data demonstrates that B5 intra-evolution and differentiation likely began within

358 HBV-infected populations resident in Asia. Thereafter, the genotype B5 coalescence among the

359 three circumpolar Arctic regions in which HBV/B5 has been observed, occurs approximately

3601100 years later (ie. approximately 900 YBP). Surprisingly, the data demonstrates that HBV/B5

361 from Greenland appears to be the "most ancient", implying that the variant present in modern

362 Greenlandic Inuit diverged from the HBV/B5 ancestor over $650 \mathrm{YBP}$, while the variants that

363 eventually form Canadian and Alaskan HBV/B5 monophyletic clades started to diverge shortly

364 thereafter. Paraskevis et al., (2013) observed a similar pattern of HBV/B5 viral evolution, such

365 that the HBV/B5 median tMRCA estimate from Alaska was determined to be more recent than

366 that from Canada or Greenland.

367

368 Based on archaeological evidence, the eastern Arctic was inhabited by the Paleo-Inuit Late

369 Dorset peoples from approximately 700 to 1300 YBP (Friesen, 2004; Maxwell, 1985). Prior to 
370 this period, the chronology of various cultural groups within the Arctic stems from a migration of

371 earlier Paleo-Inuit peoples from Siberia over 4000 YBP (Achilli et al., 2013; Friesen, 2016;

372 Gilbert et al., 2008). Archaeological evidence further shows that Neo-Eskimo people, also

373 genetically and culturally associated with ancient Siberian peoples (Raghavan et al., 2014),

374 rapidly migrated from regions of Alaska through to the eastern Arctic starting approximately 900

375 to 700 YBP (Friesen \& Arnold, 2008; McGhee, 2000; Moltke et al., 2015; Morrison, 1999). The

376 Earliest Neo-Eskimo migrants to the Eastern Arctic are known as Thule, and are accepted as the

377 ancestors of modern Inuit, with little evidence of genetic mixing between Late Dorset and Thule

378 peoples (Raghavan et al., 2014). By 600-500 YBP, transformation of the homogeneous Thule

379 culture into more diverse cultural groupings had started in a process that lasted for several

380 centuries, based on archaeological observation of shifts in regional populations, settlement

381 patterns and social organization (Friesen, 2010). The impetus for this transformation has been

382 speculated to involve climatic changes leading to increased sea ice and alteration in subsistence

383 sources (Finkelstein, Ross \& Adams, 2009) as well as changing internal social networks and

384 increasing external contact and trade with European explorers, whalers and merchants (Friesen,

385 2010; McGhee, 1994).

386

387 The genotype B5 genomic coalescence determined in the present study suggests that HBV/B5

388 was present in the Neo-Eskimo populations that travelled eastward and populated northwestern

389 Greenlandic sites. Recent evidence points to the pioneering Greenlandic Inuit population as a

390 historically isolated founder population, demonstrated by decreased nucleotide diversity (Moltke

391 et al., 2015). Prolonged isolation among a relatively small, HBV-endemically infected

392 population, may result in viral adaptation, which in turn is associated with a slower viral 
393 evolutionary rate (Lin et al., 2015; Zehender et al., 2014), possibly resulting in slow or static

394 nucleotide divergence up until the time of HBV population expansion. The Bayesian skyline plot 395 data shows HBV/B5 expansion between 400 to 250 YBP, coincident with timing of a complex

396 transformation of the Neo-Eskimo Thule people into more diverse cultural forms consistent with 397 modern Inuit. Counter-intuitively, the evolutionary history of HBV/B5 within the Arctic appears 398 to start with a Greenlandic ancestor, by way of an earlier Asian ancestor. However, this pattern 399 actually fits one of the central aspects of current models of the Thule migration from Alaska to 400 the eastern Arctic. Archaeological site distributions indicate that the initial migration was rapid, 401 and involved groups from more than one area in the Alaska / Bering Strait region. The earliest 402 populations in the northwest Greenland / northern Ellesmere Island region are known as "Ruin 403 Island Thule", and are widely accepted as; a) among the earliest, or possibly the absolute earliest, 404 Thule population in the eastern Arctic; b) somewhat different from early Thule elsewhere in the 405 Canadian Arctic, based on their material culture; and c) originating in the Bering Strait region, 406 rather than northern Alaska where other migrating Thule populations are likely to have come 407 from (Friesen, 2016; Gulløv \& McGhee, 2006; Marchani, Rogers \& O'Rourke, 2007;

408 McCullough, 1989; Morrison, 1999). The HBV/B5 pattern is consistent with this reconstruction, 409 and could represent an initial Ruin Island Thule population carrying B5 from the Bering Strait 410 region into northwest Greenland, followed by migration of other Alaskan Thule populations into 411 the Canadian Arctic, followed in turn by the spread of B5 back through those later Thule 412 populations from east to west. This east to west 'back-migration' within the high Arctic has been 413 suggested through tMRCA dating of the $\mathrm{Y}$ chromosome (Olofsson et al., 2015), mtDNA variant 414 analysis (Raff et al., 2015; Tamm et al., 2007), SNP genotyping (Reich et al., 2012) and 415 linguistic analysis (Hammarström et al., 2015; Raff et al., 2015; Sicoli \& Holton, 2014). 
417 Once large scale B5 expansion occurred, horizontal transmission and viral "colonization" likely

418 resulted in a more rapid substitution rate (Lin et al., 2015), eventually leading to an HBV/B5

419 variant having characteristics observed in modern populations, such as a significantly higher

420 nucleotide diversity (Kowalec et al., 2013; Osiowy et al., 2006) compared to other HBV

421 genotypes which infect indigenous populations, and a high prevalence of the precore A1896 stop

422 codon mutation. HBV/B5 has been hypothesized to function as an "adaptor" variant, such that it

423 excels at escaping host immune selection through its rapid mutation rate, but likely at the cost of

424 high replicative activity, or viral load, thus resulting in lowered transmission. A continued

425 association with the newly infected, yet regionally isolated transitional populations throughout

426 the Arctic would further allow for adaptation in the form of pathogen attenuation, permitting a

427 balance between viral escape leading to persistence, and host immune control, resulting in a lack

428 of immune-mediated liver disease (Minuk et al., 2013).

430 The present study has several limitations, including sampling bias and a paucity of HBV/B5

431 sequence data from certain regions. The theory of HBV/B5 evolution and spread in an eastward

432 direction would possibly be supported by obtaining HBV/B5 samples from regions of Siberia to

433 be included in phylogeographical analysis; however, such samples have not yet been identified.

434 HBV co-infection with hepatitis D virus (HDV) has been shown to be high in certain West

435 Greenland communities (Børresen et al., 2010; Langer, Frösner \& von Brunn, 1997) and it is

436 possible that co-infection may influence the short-term evolutionary rate of HBV in these

437 individuals, thus affecting the molecular clock rate. Although HBV-infected persons from whom 
438 B5 sequences were obtained from East Greenland were found to be negative for antibody to

439 HDV, the same is not known for the West Greenland sequences.

440

\section{Conclusions}

442 Through our novel phylogeographic approach, the origin and spread of HBV/B5 throughout the 443 western circumpolar Arctic has been estimated to occur coincident with the movement and 444 settlement of Neo-Eskimo populations within the past 1000 years. Results of this study and the 445 knowledge of the unique association of HBV/B5 with indigenous populations of this region, 446 including historical endemicity and a benign clinical outcome, further support the hypothesis of 447 long-term co-evolution between virus and host, and illustrate the many intricate interactions 448 between a specific variant and an infected population over time. 


\section{Acknowledgements}

452

453

454 The authors gratefully acknowledge Elizabeth Giles and Chris Huynh for excellent technical 455 assistance in HBV sample sequencing and thank all study participants.

456

457 


\section{References}

459

460 Achilli A, Perego U, Lancioni H, Olivieri A, Gandini F, Kashani B, Battaglia V, Grugni V,

461 Angerhofer N, Rogers M, Herrera R, Woodward S, Labuda D, Smith D, Cybulski J, Semino O,

462 Malhi R, Torroni A. 2013. Reconciling migration models to the Americas with the variation of

463 North American native mitogenomes. Proceedings of the National Academy of Sciences USA,

464 110:14308-14313. DOI:10.1073/pnas.1306290110.

465 Bar-Gal G, Kim M, Klein A, Shin D, Oh C, Kim J, Kim T, Kim S, Grant P,

466 Pappo,O.,Spigelman,M., Shouval D. 2012. Tracing hepatitis B virus to the 16th century in a 467 Korean mummy. Hepatology, 56:1671-1680. DOI: 10.1002/hep.25852.

468 Børresen ML, Olsen O, Ladefoged K, McMahon BJ, Hjuler T, Panum I, Simonetti J, Jones C,

469 Krarup H, Koch A. 2010. Hepatitis D outbreak among children in a hepatitis B hyper-endemic

470 settlement in Greenland. Journal of Viral Hepatitis, 17:162-170. DOI: 10.1111/j.1365-

471 2893.2009.01159.x.

472 Bouckaert R, Alvarado-Mora M, Pinho J. 2013. Evolutionary rates and HBV: issues of rate

473 estimation with Bayesian molecular methods. Antiviral Therapy, 18:497-503. DOI:

$474 \quad$ 10.3851/IMP2656.

475 Bouckaert R, Heled J, Kühnert D, Vaughan T, Wu C, Xie D, Suchard M, Rambaut A,

476 Drummond A. 2014. BEAST 2: A software platform for Bayesian evolutionary analysis. PLoS

477 Computational Biology, 10:e1003537. DOI: 10.1371/journal.pcbi.1003537. 
478 Bouckaert R, Lemey P, Dunn M, Greenhill S, Alekseyenko A, Drummond A, Gray R, Suchard

479 M, Atkinson Q. 2012. Mapping the origins and expansion of the Indo-European language family.

480 Science, 337:957-960. DOI: 10.1126/science.1219669.

481 Central Intelligence Agency. 2015. The World Factbook (Greenland). Available at

482 https://www.cia.gov/library/publications/the-world-factbook/geos/gl.html (accessed 26 October

483 2016).

484 Drummond A, Bouckaert R. 2015. Bayesian Evolutionary Analysis with BEAST. 1st ed. United 485 Kingdom: Cambridge University Press.

486 Drummond A, Ho SYW, Phillips M, Rambaut A. 2006. Relaxed phylogenetics and dating with 487 confidence. PLos Biology, 4:e88. DOI: 10.1371/journal.pbio.0040088.

488 Drummond A, Rambaut A, Shapiro B, Pybus O. 2005. Bayesian coalescent inference of past 489 population dynamics from molecular sequences. Molecular Biology and Evolution, 22:1185490 1192. DOI: $10.1093 / \mathrm{molbev} / \mathrm{msi103.}$

491 Felsenstein J. 1981. Evolutionary trees from DNA sequences: a maximum likelihood approach. 492 Journal of Molecular Evolution, 17:368-376.

493 Finkelstein SA, Ross JM, Adams JK. 2009. Spatiotemporal variability in Arctic climates of the 494 past millennium: Implications for the study of Thule culture on Melville Peninsula, Nunavut. 495 Arctic, Antarctic, and Alpine Research, 41:442-454. 
496 Friesen TM. 2016. Pan-Arctic Population Movements: The Early Paleo-Inuit and Thule Inuit 497 Migrations. In: Friesen TM, Mason O, eds. The Oxford Handbook of the Prehistoric Arctic. New 498 York: Oxford University Press, 673-692.

499 Friesen TM. 2010. Dynamic Inuit social strategies in changing environments: A long-term 500 perspective. Geografisk Tidsskrift-Danish Journal of Geography, 110:215-225.

501 Friesen TM. 2004. Contemporaneity of Dorset and Thule cultures in the North American Arctic: 502 New radiocarbon dates from Victoria Island, Nunavut. Current Anthropology, 45:685-691. DOI: $50310.1086 / 425635$.

504 Friesen TM, Arnold CD. 2008. The timing of the Thule migration: New dates from the western 505 Canadian Arctic. American Antiquity, 73:527-538.

506 Gilbert MT, Kivisild T, Grønnow B, Andersen P, Metspalu E, Reidla M, Tamm E, Axelsson E, 507 Götherström A, Campos P, Rasmussen M, Metspalu M, Higham T, Schwenninger J, Nathan R, 508 De Hoog C, Koch A, Møller L, Andreasen C, Meldgaard M, Villems R, Bendixen C, Willerslev 509 E. 2008. Paleo-eskimo mtDNA genome reveals matrilineal discontinuity in Greenland. Science, 510 320:1787-1789. DOI: 10.1126/science.1159750.

511 Gulløv HC, McGhee R. 2006. Did Bering Strait people initiate the Thule migration? Alaska 512 Journal of Anthropology, 4:54-63.

513 Hammarström H, Forkel R, Haspelmath M, Bank S. 2015. Glottolog 2.6 (Jena: Max Planck 514 Institute for the Science of Human History): "Yupik". Available at 515 http://glottolog.org/glottolog?search=Yupik\#4/63.03/199.02 (accessed 27 October 2015). 
516 Harrison A, Lemey P, Hurles M, Moyes C, Horn S, Pryor J, Malani J, Supuri M, Masta A,

517 Teriboriki B, Toatu T, Penny D, Rambaut A, Shapiro B. 2011. Genomic analysis of hepatitis B

518 virus reveals antigen state and genotype as sources of evolutionary rate variation. Viruses, 3:83-

519 101. DOI: $10.3390 / \mathrm{v} 3020083$.

520 Hasegawa M, Kishino H, Yano T. 1985. Dating of the human-ape splitting by a molecular clock

521 of mitochondrial DNA. Journal of Molecular Evolution, 22:160-174.

522 Heled J, Bouckaert R. 2013. Looking for trees in the forest: summary tree from posterior

523 samples. BMC Evolutionary Biology, 13:221. DOI: 10.1186/1471-2148-13-221.

524 Helgason A, Pálsson G, Pedersen H, Angulalik E, Gunnarsdóttir E, Yngvadóttir B, Stefánsson K.

525 2006. mtDNA variation in Inuit populations of Greenland and Canada: Migration history and

526 population structure. American Journal of Physical Anthropology, 130:123-134. DOI:

527 10.1002/ajpa.20313.

528 Horikita M, Itoh S, Yamamoto K, Shibayama T, Tsuda F, Okamoto H. 1994. Differences in the

529 entire nucleotide sequence between hepatitis B virus genomes from carriers positive for antibody

530 to hepatitis B e antigen with and without active disease. Journal of Medical Virology, 44:96-103.

531 Huynh C, Minuk GY, Uhanova J, Baikie M, Vardy L, Wong T, Osiowy C. 2014. Serological and

532 molecular epidemiological outcomes after two decades of universal infant hepatitis B virus

533 (HBV) vaccination in Nunavut, Canada. Hepatology, 60:975A.

534 Inoue J, Ueno Y, Wakui Y, Fukushima K, Kondo Y, Kakazu E, Ninomiya M, Niitsuma H,

535 Shimosegawa T. 2011. Enhanced replication of hepatitis B virus with frameshift in the precore 
536 region found in fulminant hepatitis patients. Journal of Infectious Diseases, 204:1017-1025.

537 DOI: 10.1093/infdis/jir485.

538 Koseki T, Hongo S, Muraki Y, Sugawara K, Matsuzaki Y, Nakamura K. 1999. Sequence

539 analysisi of the entire genome of hepatitis B virus from a patient with fulminant hepatitis.

540 Yamagata Medical Journal, 17:27-40.

541 Kowalec K, Minuk GY, Børresen M, Koch A, McMahon BJ, Simons B, Osiowy C. 2013.

542 Genetic diversity of hepatitis B virus genotypes B6, D and F among circumpolar indigenous

543 individuals. Journal of Viral Hepatitis, 20:122-130. DOI: 10.1111/j.1365-2893.2012.01632.x.

544 Kramvis A. 2014. Genotypes and genetic variability of hepatitis B virus. Intervirology, 57:141-

545 150. DOI: $10.1159 / 000360947$.

546 Krarup H, Andersen S, Madsen P, Okkels H, Hvingel B, Laurberg P. 2008. Benign course of

547 long-standing hepatitis B virus infection among Greenland Inuit? Scandinavian Journal of

548 Gastroenterology, 43:334-343. DOI: 10.1080/00365520701712198.

549 Langer B, Frösner G, von Brunn A. 1997. Epidemiological study of viral hepatitis types A, B, C,

550 D and E among Inuits in West Greenland. Journal of Viral Hepatitis, 4:339-349.

551 Larke RPB, Froese G, Devine R, Petruk M. 1987. Extension of the epidemiology of hepatitis B

552 in circumpolar regions through a comprehensive serologic study in the Northwest Territories of 553 Canada. Journal of Medical Virology, 22:269-276.

554 Lauring AS, Andino R. 2010. Quasispecies theory and the behavior of RNA viruses. PLoS

555 Pathogens, 6:e1001005. DOI: 10.1371/journal.ppat.1001005. 
556 Lin Y, Liu C, Chien W, Wu L, Tao Y, Wu D, Lu X, Hsieh C, Chen P, Wang H, Kao J, Chen DS.

557 2015. New insights into the evolutionary rate of hepatitis B virus at different biological scales.

558 Journal of Virology, 89:3512-3522. DOI: 10.1128/JVI.03131-14.

559 Littlejohn M, Locarnini S, Yuen L. 2016. Origins and evolution of hepatitis B virus and hepatitis

560 D virus. Cold Spring Harbor Perspectives in Medicine, 6:a021360.

561 DOI:10.1101/cshperspect.a021360.

562 Marchani EE, Rogers AR, O'Rourke DH. 2007. The Thule migration: Rejecting population

563 histories using computer simulation. American Journal of Physical Anthropology, 134:281-284.

564 DOI: 10.1002/ajpa.20650.

565 Maxwell MS. 1985. Prehistory of the Eastern Arctic. Orlando: Academic Press.

566 McCullough K. 1989. The Ruin Islanders: Early Thule Culture Pioneers in the Eastern High 567 Arctic. Ottawa: Canadian Museum of Civilization.

568 McGhee R. 2000. Radiocarbon dating and the timing of the Thule migration. In: Appelt M, 569 Berglund J, Gulløv HC, eds. Identities and Cultural Contacts in the Arctic: Proceedings from a 570 Conference at the Danish National Museum, Copenhagen, November 30 to December 2, 1999.

571 Copenhagen: Danish Polar Center, 181-191.

572 McGhee R. 1994. Disease and the development of Inuit culture. Current Anthropology, 35:565573594.

574 McMahon BJ. 2004. Viral hepatitis in the Arctic. International Journal of Circumpolar Health, 575 63:41-48. DOI: 10.3402/ijch.v63i0.17784. 
576 McMahon BJ, Bulkow L, Singleton R, Williams J, Snowball M, Homan C, Parkinson A. 2011.

577 Elimination of hepatocellular carcinoma and acute hepatitis B in children 25 years after a

578 hepatitis B newborn and catch-up immunization program. Hepatology, 54:801-807. DOI:

579 10.1002/hep.24442.

580 Meldal BH, Bon AH, Prati D, Ayob Y, Allain JP. 2011. Diversity of hepatitis B virus infecting

581 Malaysian candidate blood donors is driven by viral and host factors. Journal of Viral Hepatitis, 582 18:91-101. DOI: 10.1111/j.1365-2893.2010.01282.x.

583 Minuk GY, Kowalec K, Caouette S, Larke B, Osiowy C. 2012. The prevalence and long term 584 outcome of occult hepatitis B virus infections in community based populations. Journal of 585 Medical Virology, 84:1369-1375. DOI: 10.1002/jmv.23351.

586 Minuk GY, Macrury S, Uhanova J, Caouette S, Coleman N, Cummings K, Larke B, Vardy L, 587 Huynh C, Osiowy C. 2013. A paucity of liver disease in Canadian Inuit with chronic hepatitis B 588 virus, subgenotype B6 infection. Journal of Viral Hepatitis, 20:890-896.

589 DOI:10.1111/jvh.12121.

590 Minuk GY, Uhanova J. 2003. Viral hepatitis in the Canadian Inuit and First Nations populations. 591 Canadian Journal of Gastroenterology, 17:707-712.

592 Moltke I, Fumagalli M, Korneliussen TS, Crawford J, Bjerregaard P, Jørgensen M, Grarup N, 593 Gulløv HC, Linneberg A, Pedersen O, Hansen T, Nielsen R, Albrechtsen A. 2015. Uncovering 594 the genetic history of the present-day Greenlandic population. American Journal of Human 595 Genetics, 96:54-69. DOI: 10.1016/j.ajhg.2014.11.012. 
596 Morrison D. 1999. The earliest Thule migration. Canadian Journal of Archaeology, 22:139-156.

597 Olofsson J, Pereira V, Børsting C, Morling N. 2015. Peopling of the north circumpolar region 598 insights from Y chromosome STR and SNP typing of Greenlanders. PLoS ONE, 10:e0116573.

599 DOI: 10.1371/journal.pone.0116573.

600 Osiowy C. 2002. Sensitive detection of HBsAg mutants by a gap ligase chain reaction assay. 601 Journal of Clinical Microbiology, 40:2566-2571.

602 Osiowy C, Giles E, Tanaka Y, Mizokami M, Minuk GY. 2006. Molecular evolution of hepatitis 603 B virus over 25 years. Journal of Virology, 80:10307-10314. DOI: 10.1128/JVI.00996-06.

604 Osiowy C, Kaita K, Solar K, Mendoza K. 2010. Molecular characterization of hepatitis B virus 605 and a 9-year clinical profile in a patient with genotype I. Journal of Medical Virology, 82:942606 948. DOI: $10.1002 / \mathrm{jmv} .21758$.

607 Osiowy C, Larke RPB, Giles E. 2011. Distinct geographical and demographic distribution of 608 hepatitis B virus genotypes in the Canadian Arctic as revealed through an extensive molecular 609 epidemiological survey. Journal of Viral Hepatitis, 18:e11-e19. DOI: 10.1111/j.1365$610 \quad 2893.2010 .01356 . x$.

611 Osiowy C, Simons B, Rempel JD. 2013. Distribution of viral hepatitis in indigenous populations 612 of North America and the circumpolar Arctic. Antiviral Therapy, 18:467-473.

613 DOI:10.3851/IMP2597.

614 Paraskevis D, Angelis K, Magiorkinis G, Kostaki E, Ho SYW, Hatzakis A. 2015. Dating the 615 origin of hepatitis B virus reveals higher substitution rate and adaptation on the branch leading to 
616 F/H genotypes. Molecular Phylogenetics and Evolution, 93:44-54.

617 DOI:10.1016/j.ympev.2015.07.010.

618 Paraskevis D, Magiorkinis G, Magiorkinis E, Ho SYW, Belshaw R, Allain J, Hatzakis A. 2013.

619 Dating the origin and dispersal of hepatitis B virus infection in humans and primates.

620 Hepatology, 57:908-916. DOI: 10.1002/hep.26079.

621 Posada D. 2003. Using MODELTEST and PAUP* to select a model of nucleotide substitution.

622 Current Protocols in Bioinformatics, Chapter 6-Unit 6.5. DOI: 10.1002/0471250953.bi0605s00.

623 Raff JA, Rzhetskaya M, Tackney J, Hayes MG. 2015. Mitochondrial diversity of Iñupiat people

624 from the Alaskan north slope provides evidence for the origins of the Paleo- and Neo-Eskimo

625 peoples. American Journal of Physical Anthropology, 157:603-614. DOI: 10.1002/ajpa.22750.

626 Raghavan M, DeGiorgio M, Albrechtsen A, Moltke I, Skoglund P, Korneliussen TS, Grønnow

627 B, Appelt M, Gulløv HC, Friesen TM, Fitzhugh W, Malmström H, Rasmussen S, Olsen J,

628 Melchior L, Fuller BT, Fahrni SM, Stafford T,Jr, Grimes V, Renouf MA, Cybulski J, Lynnerup

629 N, Lahr MM, Britton K, Knecht R, Arneborg J, Metspalu M, Cornejo OE, Malaspinas AS, Wang

630 Y, Rasmussen M, Raghavan V, Hansen TV, Khusnutdinova E, Pierre T, Dneprovsky K,

631 Andreasen C, Lange H, Hayes MG, Coltrain J, Spitsyn VA, Götherström A, Orlando L, Kivisild

632 T, Villems R, Crawford MH, Nielsen FC, Dissing J, Heinemeier J, Meldgaard M, Bustamante C,

633 O'Rourke DH, Jakobsson M, Gilbert MT, Nielsen R, Willerslev E. 2014. The genetic prehistory

634 of the New World Arctic. Science, 345:1255832. DOI: 10.1126/science.1255832.

635 Reich D, Patterson N, Campbell D, Tandon A, Mazieres S, Ray N, Parra M, Rojas W, Duque C,

636 Mesa N, Garcia L, Triana O, Blair S, Maestre A, Dib J, Bravi C, Bailliet G, Corach D, 
637 Hunemeier T, Bortolini M, Salzano F, Petzl-Erler M, Acuna-Alonzo V, Aguilar-Salinas C,

638 Canizales-Quinteros S, Tusie-Luna T, Riba L, Rodriguez-Cruz M, Lopez-Alarcon M, Coral-

639 Vazquez R, Canto-Cetina T, Silva-Zolezzi I, Fernandez-Lopez J, Contreras A, Jimenez-Sanchez

640 G, Gomez-Vazquez M, Molina J, Carracedo A, Salas A, Gallo C, Poletti G, Witonsky D,

641 Alkorta-Aranburu G, Sukernik R, Osipova L, Fedorova S, Vasquez R, Villena M, Moreau C,

642 Barrantes R, Pauls D, Excoffier L, Bedoya G, Rothhammer F, Dugoujon J, Larrouy G, Klitz W,

643 Labuda D, Kidd J, Kidd K, Di Rienzo A, Freimer N, Price A, Ruiz-Linares A. 2012.

644 Reconstructing Native American population history. Nature, 488:370-374. DOI:

$64510.1038 /$ nature11258.

646 Sakamoto T, Tanaka Y, Simonetti J, Osiowy C, Børresen M, Koch A, Kurbanov F, Sugiyama M,

647 Minuk GY, McMahon BJ, Joh T, Mizokami M. 2007. Classification of hepatitis B virus

648 genotype B into 2 major types based on characterization of a novel subgenotype in Arctic

649 indigenous populations. The Journal of Infectious Diseases, 196:1487-1492.

650 DOI:10.1086/523111.

651 Sicoli MA, Holton G. 2014. Linguistic phylogenies support back-migration from Beringia to

652 Asia. PLoS ONE, 9:e91722. DOI: 10.1371/journal.pone.0091722.

653 Statistics Canada. 2014. Aboriginal Peoples in Canada: First Nations People, Métis and Inuit

654 (National Household Survey, Analytical Products, 2011). Available at

655 http://www12.statcan.gc.ca/nhs-enm/2011/as-sa/99-011-x/99-011-x2011001-eng.cfm\#wb-head

656 (accessed 26 October 2015). 
657 Sugauchi F, Orito E, Ichida T, Kato H, Sakugawa H, Kakumu S, Ishida T, Chutaputti A, Lai CL,

658 Ueda R, Miyakawa Y, Mizokami M. 2002. Hepatitis B virus of genotype B with or without

659 recombination with genotype C over the precore region plus the core gene. Journal of Virology,

$660 \quad 76: 5985-5992$.

661 Suh A, Brosius J, Schmitz J, Ole Kriegs J. 2013. The genome of a Mesozoic paleovirus reveals

662 the evolution of hepatitis B viruses. Nature Communications, 4:1791.

663 DOI:10.1038/ncomms2798.

664 Tamm E, Kivisild T, Reidla MM,M., Smith D, Mulligan C, Bravi C, Rickards O, Martinez-

665 Labarga C, Khusnutdinova E, Fedorova S, Golubenko M, Stepanov V, Gubina M, Shadanov S,

666 Ossipova L, Damba L, Voevoda M, Dipierri J, Villems R, Malhi R. 2007. Beringian standstill

667 and spread of Native American founders. PLoS ONE, 2:e829.

668 DOI:10.1371/journal.pone.0000829.

669 Tamura K, Nei M. 1993. Estimation of the number of nucleotide substitutions in the control

670 region of mitochondrial DNA in humans and chimpanzees. Molecular Biology and Evolution,

$671 \quad 10: 512-526$.

672 Tavaré S. 1986. Some probabilistic and statistical problems in the analysis of DNA sequences.

673 Lectures on Mathematics in the Life Sciences, 17:57-86.

674 Tedder RS, Bissett S, Myers R, Ijaz S. 2013. The 'Red Queen' dilemma - running to stay in the

675 same place: reflections on the evolutionary vector of HBV in humans. Antiviral Therapy,

676 18:489-496. DOI: 10.3851/IMP2655. 
677 Thompson JD, Gibson TJ, Plewniak F, Jeanmougin F, Higgins DG. 1997. The ClustalX

678 windows interface: flexible strategies for multiple sequence alignment aided by quality analysis 679 tools. Nucleic Acids Research, 24:4876-4882.

680 Tulisov A, McMahon BJ, Koch A, Minuk GY, Chulanov V, Bruce MG, Uhanova J, Børresen M, 681 Williams J, Osiowy C, Gelvan A, Alexeeva M, Larke B, Watt K. 2007. Viral hepatitis in the 682 Arctic. A review from a Circumpolar Workshop on Viral hepatitis, ICCH13. Alaska Medicine, 683 49:193-203.

684 United States Census Bureau. 2012. American Indian and Alaska Native Population: 2010. 685 Available at http://www.census.gov/prod/cen2010/briefs/c2010br-10.pdf (accessed 26 October 686 2015). Xu Z, Ren X, Liu Y, Li X, Bai S, Zhong Y, Wang L, Mao P, Wang H, Xin S, Wong VW, Chan 688 HL, Zoulim F, Xu D. 2011. Association of hepatitis B virus mutations in basal core promoter and 689 precore regions with severity of liver disease: an investigation of 793 Chinese patients with mild and severe chronic hepatitis B and acute-on-chronic liver failure. Journal of Gastroenterology, 691 46:391-400. DOI: 10.1007/s00535-010-0315-4. 
697 Figure 1. Relative rates (y-axis) and partitions among the HBV nucleotide site (x-axis), labelled with dominant substitution models

698 for the partition following reversible-jump-based substitution model analysis. The overlapping gene coding regions for the

699 approximately $3200 \mathrm{bp} \mathrm{HBV}$ genome are illustrated above the graph (Pol, polymerase). The genome was split into different partitions,

700 since the HBV genome has many regions with overlapping coding frames, and each region can be expected to be governed by

701 different evolutionary processes, explaining the difference in substitution models and average rates. GTR, General Time Reversible

702 Model; TAN, Tamura and Nei; TIM, Transitional Model. 


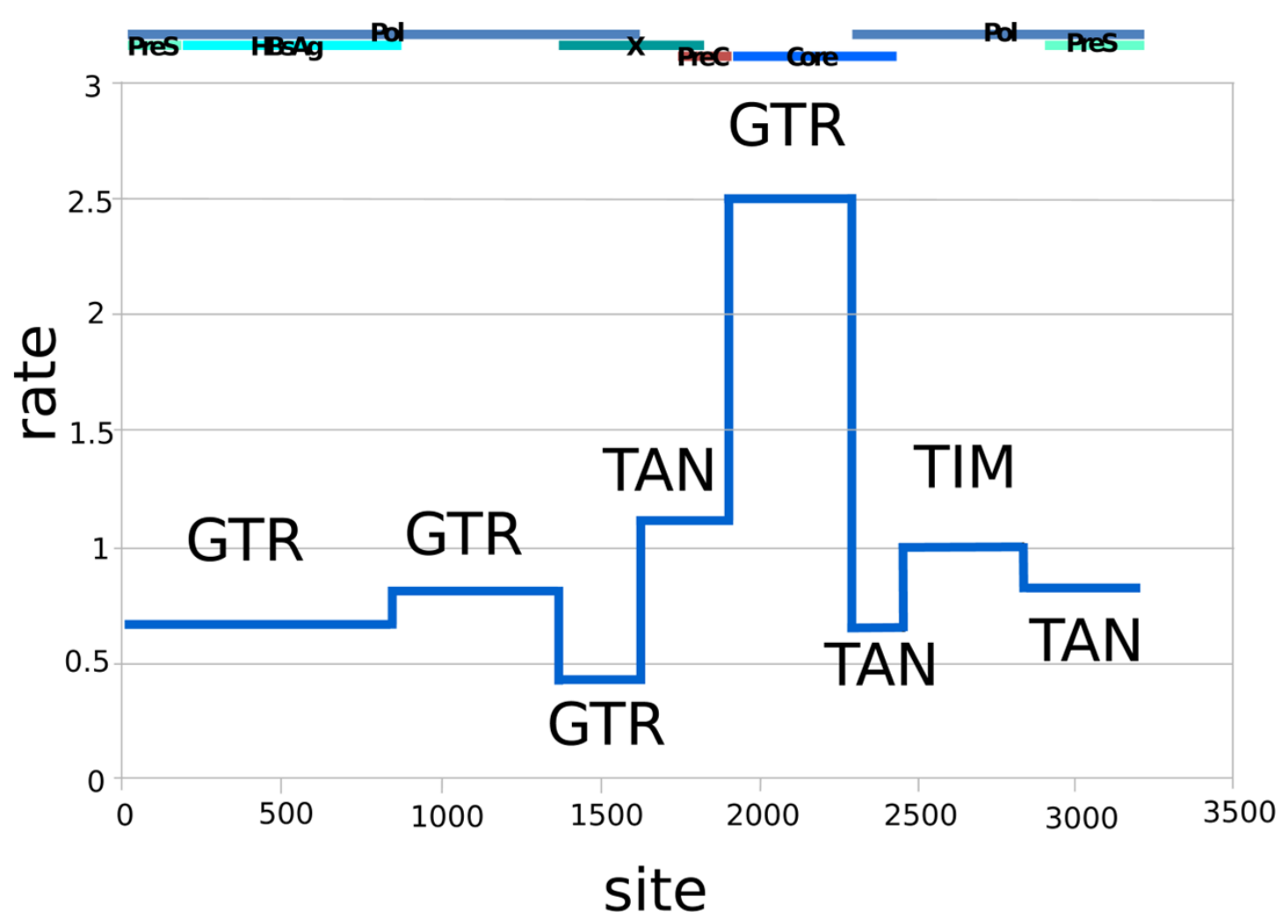

704 Figure 2. DensiTree showing clustering of HBV sequences within geographic locations. The consensus tree is shown by the bold blue

705 line and the estimated tMRCA years before present for tree nodes are shown at the top of the tree. Uncertainty of node heights and

topology is shown by the transparent green lines. The clade on the top of the tree ("Asia") consists of HBV genotype B1 and B2 on archeological evidence of the Thule expansion at that time. 


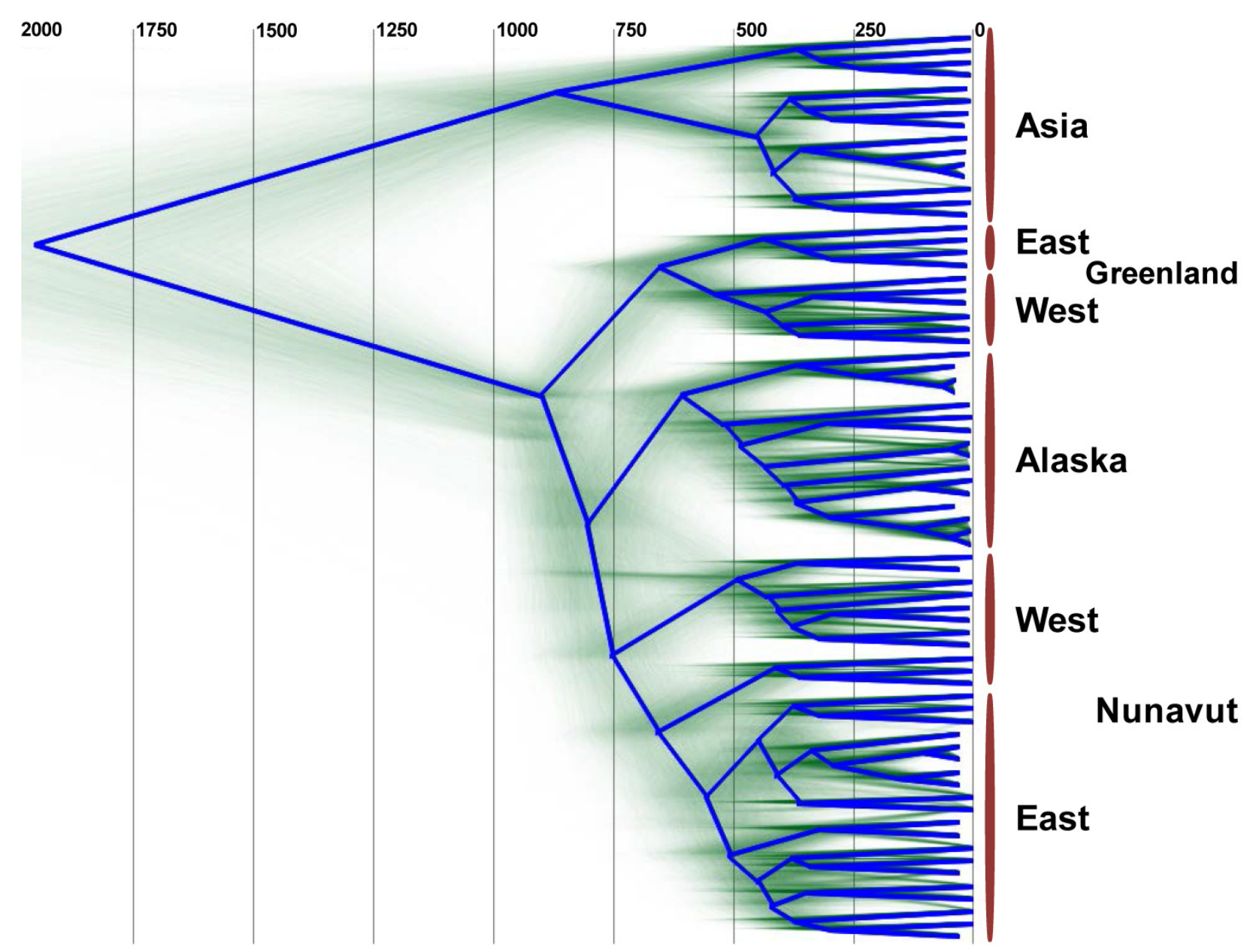

710 Figure 3. Effective population estimates of the HBV/B5 population (y-axis) over the years before present (x-axis) based on the

711 Bayesian skyline plot. The median effective population size is shown by the bold black line, with the $95 \%$ highest posterior density

712 indicated in blue. The timeframe spans 1200 YBP to present day. 


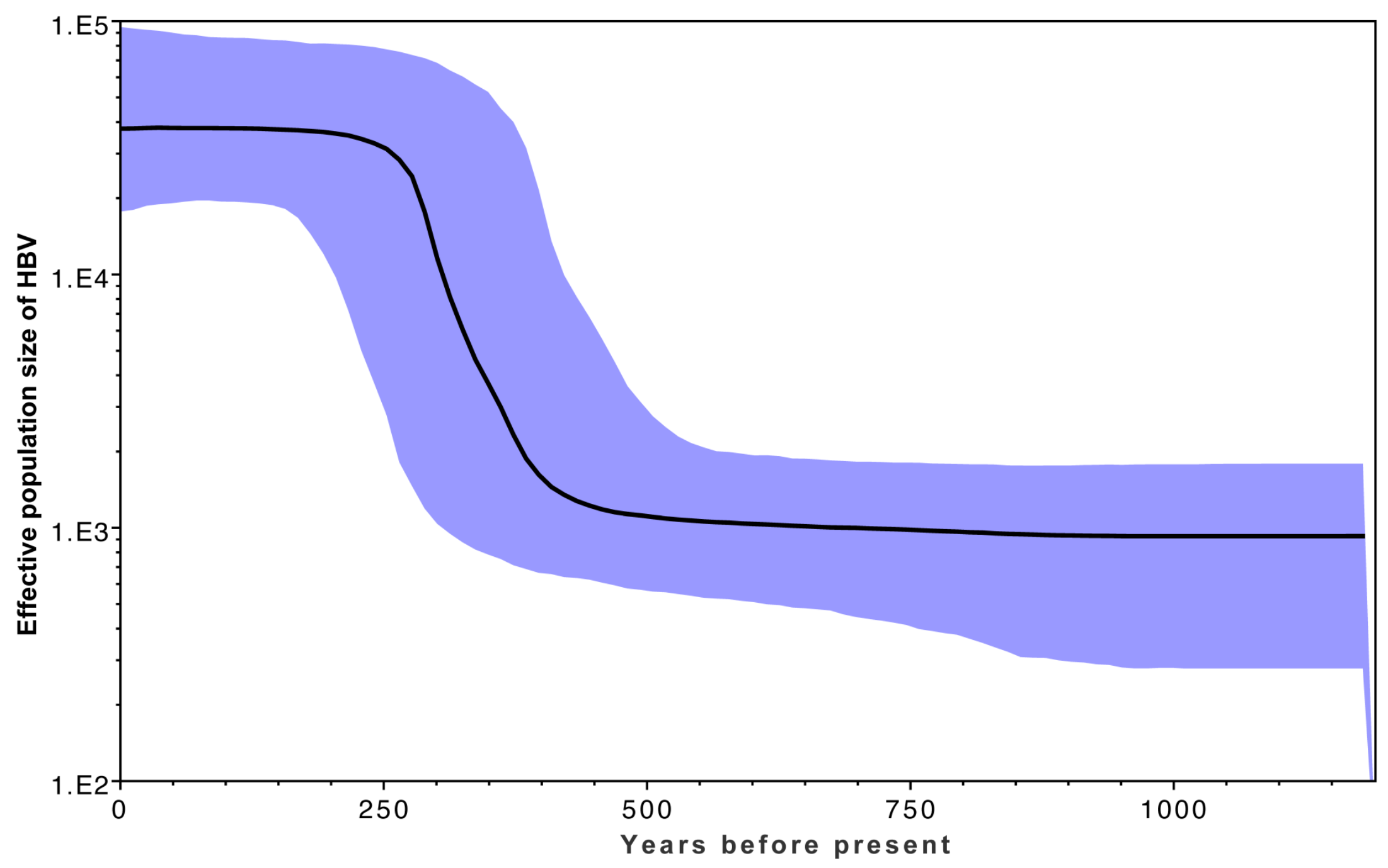

714 Figure 4. Estimated HBV dispersal routes into the high eastern Arctic, shown as a progression through time at times 900 YBP (A),

715600 YBP (B) and present (C). The blue line indicates the most plausible (highest probability) route of HBV dispersal based on 
716 landscape aware modelling. The coloured dots indicate the posterior distribution of dispersal. The dots are coloured by time, from

717 light blue (earliest), green, yellow, orange, and red (most current). Background map from Wikimedia Commons

718 (https://commons.wikimedia.org/wiki/File:World98.svg). An animation of the landscape aware geographic model analysis which

719 demonstrates the entire dispersal estimation over time and from which Fig. 4 is taken is provided as a supplemental file (Video S1).
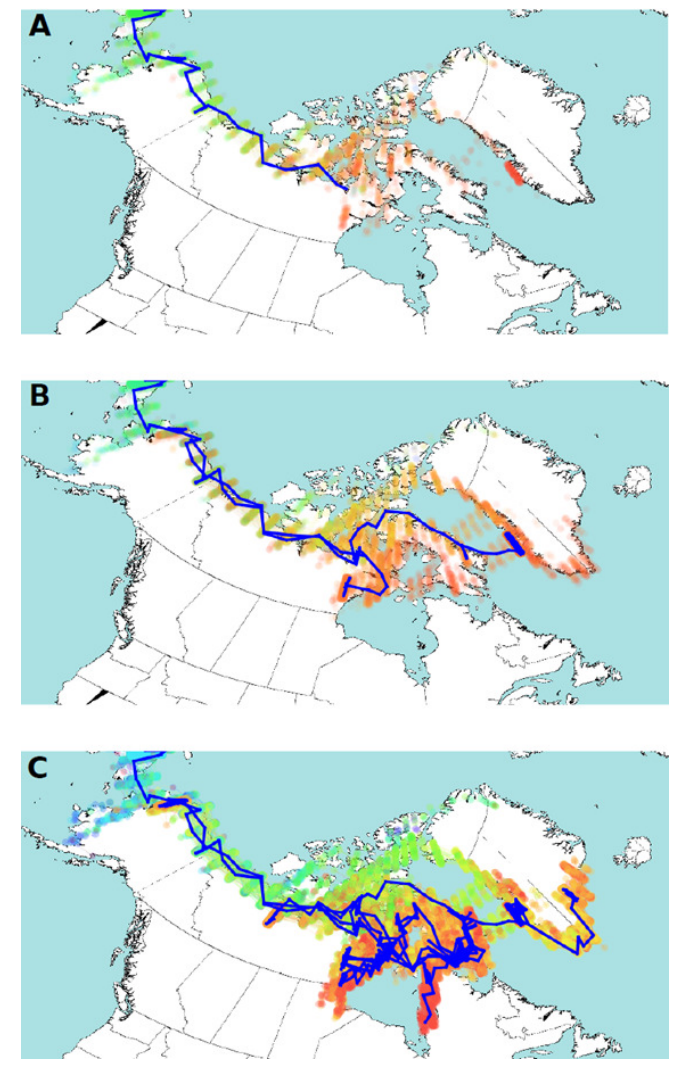
722 Table 1. Sample date, location, and molecular properties of sequences included in the analysis 723

\begin{tabular}{|c|c|c|c|c|c|c|c|}
\hline $\begin{array}{l}\text { GenBank } \\
\text { Accession \# }\end{array}$ & $\begin{array}{c}\text { HBV } \\
\text { sub- } \\
\text { genotyp } \\
\text { e }\end{array}$ & $\begin{array}{l}\text { G1896 } \\
\text { A }\end{array}$ & $\begin{array}{l}\text { Full or } \\
\text { partial } \\
\text { genome }\end{array}$ & $\begin{array}{l}\text { Partial genome } \\
\text { region included } \\
\text { (nucleotide)* }\end{array}$ & $\begin{array}{l}\text { Location } \\
\text { information }\end{array}$ & Sample dates & Reference \\
\hline \multicolumn{8}{|c|}{ ALASKA } \\
\hline KР659219 & B5 & A1896 & Full & & Alaska & 07-Feb-2006 & Present study \\
\hline КР659220 & B5 & A1896 & Full & & Alaska & 26-Oct-2005 & Present study \\
\hline KP659221 & B5 & A1896 & Full & & Alaska & 25-Jan-2005 & Present study \\
\hline КР659222 & B5 & A1896 & Partial & $\begin{array}{c}153-881 ; 1839- \\
3215\end{array}$ & Alaska & 12-May-2003 & Present study \\
\hline КР659223 & B5 & A1896 & Full & & Alaska & 15-Sep-2003 & Present study \\
\hline КР659224 & B5 & A1896 & Full & & Alaska & 10-Dec-2008 & Present study \\
\hline КР659225 & B5 & G1896 & Partial & $\begin{array}{c}13-866 ; 1360- \\
1774 ; 2347-3142\end{array}$ & Alaska & 01-Sep-2008 & Present study \\
\hline КР659226 & B5 & G1896 & Partial & $\begin{array}{c}13-884 ; 1002- \\
1397 ; 2338-3168\end{array}$ & Alaska & 18-Jun-2003 & Present study \\
\hline КР659227 & B5 & G1896 & Partial & $155-834$ & Alaska & 14-Dec-2006 & Present study \\
\hline КР659228 & B5 & G1896 & Partial & $155-834$ & Alaska & 29-Apr-2003 & Present study \\
\hline AB287314 & B5 & G1896 & Full & & Alaska & 23-Oct-1973 & Sakamoto et al., 2007 \\
\hline $\mathrm{AB} 287315$ & B5 & G1896 & Full & & Alaska & 19-Mar-1975 & Sakamoto et al., 2007 \\
\hline AB287316 & B5 & A1896 & Full & & Alaska & 23-Oct-1973 & Sakamoto et al., 2007 \\
\hline AB287317 & B5 & A1896 & Full & & Alaska & 21-Mar-1974 & Sakamoto et al., 2007 \\
\hline AB287318 & B5 & A1896 & Full & & Alaska & 01-Jan-2004 & Sakamoto et al., 2007 \\
\hline AB287319 & B5 & A1896 & Full & & Alaska & 29-Jan-2004 & Sakamoto et al., 2007 \\
\hline \multicolumn{8}{|c|}{ CANADA } \\
\hline КР659234 & B5 & G1896 & Full & & $\begin{array}{c}\text { West } \\
\text { Nunavut }\end{array}$ & 08-Oct-1983 & $\begin{array}{c}\text { Osiowy, Larke \& Giles, 2011; } \\
\text { Present study }\end{array}$ \\
\hline КР659235 & B5 & G1896 & Full & & $\begin{array}{l}\text { West } \\
\text { Nunavut }\end{array}$ & 08-Oct-1983 & $\begin{array}{l}\text { Osiowy, Larke \& Giles, 2011; } \\
\text { Present study }\end{array}$ \\
\hline КР659236 & B5 & A1896 & Partial & $\begin{array}{c}1-258 ; 803-1775 \\
1838-3215\end{array}$ & $\begin{array}{c}\text { West } \\
\text { Nunavut }\end{array}$ & 21-Apr-1984 & $\begin{array}{l}\text { Osiowy, Larke \& Giles, 2011; } \\
\text { Present study }\end{array}$ \\
\hline KP659237 & B5 & G1896 & Full & & East Nunavut & 23-Oct-1983 & $\begin{array}{c}\text { Osiowy, Larke \& Giles, 2011; } \\
\text { Present study }\end{array}$ \\
\hline KP659238 & B5 & A1896 & Partial & $\begin{array}{l}1-1770 ; 2375- \\
3215\end{array}$ & $\begin{array}{c}\text { West } \\
\text { Nunavut }\end{array}$ & 06-Mar-1984 & $\begin{array}{c}\text { Osiowy, Larke \& Giles, 2011; } \\
\text { Present study }\end{array}$ \\
\hline КР659239 & B5 & A1896 & Partial & $\begin{array}{l}1-1778 ; 1839- \\
3215\end{array}$ & $\begin{array}{c}\text { West } \\
\text { Nunavut }\end{array}$ & 16-Mar-1984 & $\begin{array}{c}\text { Osiowy, Larke \& Giles, 2011; } \\
\text { Present study }\end{array}$ \\
\hline КР659240 & B5 & A1896 & Partial & $\begin{array}{l}1-1793 ; 1838- \\
3215\end{array}$ & East Nunavut & 01-May-2012 & $\begin{array}{c}\text { Minuk et al., 2013; Present } \\
\text { study }\end{array}$ \\
\hline КР659241 & B5 & A1896 & Partial & $\begin{array}{c}1-254 ; 803-1792 \\
1833-3215\end{array}$ & East Nunavut & 28-Apr-2012 & $\begin{array}{l}\text { Minuk et al., 2013; Present } \\
\text { study }\end{array}$ \\
\hline KР659242 & B5 & A1896 & Partial & $\begin{array}{c}1-253 ; 780-1770 \\
1840-2848 ; 2867- \\
3215\end{array}$ & East Nunavut & 27-Apr-2012 & $\begin{array}{l}\text { Minuk et al., 2013; Present } \\
\text { study }\end{array}$ \\
\hline КР659243 & B5 & A1896 & Partial & $\begin{array}{c}1-898 ; 969-1333 \\
1666-2405 ; 2825- \\
3215\end{array}$ & East Nunavut & 15-Sep-1983 & $\begin{array}{c}\text { Osiowy, Larke \& Giles, 2011; } \\
\text { Present study }\end{array}$ \\
\hline КР659244 & B5 & A1896 & Partial & $\begin{array}{c}1-1792 ; 1839- \\
3215\end{array}$ & East Nunavut & 26-Apr-1983 & $\begin{array}{c}\text { Osiowy, Larke \& Giles, 2011; } \\
\text { Present study }\end{array}$ \\
\hline KP659245 & B5 & A1896 & Full & & East Nunavut & 09-May-2012 & $\begin{array}{c}\text { Minuk et al., 2013; Present } \\
\text { study }\end{array}$ \\
\hline KР659246 & B5 & A1896 & Full & & East Nunavut & 23-Oct-1983 & Osiowy, Larke \& Giles, 2011; \\
\hline
\end{tabular}




\begin{tabular}{|c|c|c|c|c|c|c|c|}
\hline КР659247 & B5 & G1896 & Full & & East Nunavut & 05-May-1983 & $\begin{array}{c}\text { Osiowy, Larke \& Giles, 2011; } \\
\text { Present study }\end{array}$ \\
\hline КР659248 & B5 & A1896 & Full & & East Nunavut & 29-Apr-2013 & $\begin{array}{l}\text { Huynh et al., 2014; Present } \\
\text { study }\end{array}$ \\
\hline КР659249 & B5 & A1896 & Full & & East Nunavut & 01-May-2013 & $\begin{array}{l}\text { Huynh et al., 2014; Present } \\
\text { study }\end{array}$ \\
\hline КР659250 & B5 & A1896 & Full & & East Nunavut & 17-Jun-2013 & $\begin{array}{l}\text { Huynh et al., 2014; Present } \\
\text { study }\end{array}$ \\
\hline KР659251 & B5 & A1896 & Full & & East Nunavut & 10-Apr-2013 & $\begin{array}{l}\text { Huynh et al., 2014; Present } \\
\text { study }\end{array}$ \\
\hline KP659252 & B5 & A1896 & Full & & East Nunavut & 22-May-2013 & $\begin{array}{l}\text { Huynh et al., 2014; Present } \\
\text { study }\end{array}$ \\
\hline KР659253 & B5 & A1896 & Full & & East Nunavut & 22-May-2013 & $\begin{array}{l}\text { Huynh et al., 2014; Present } \\
\text { study }\end{array}$ \\
\hline KР659254 & B5 & A1896 & Full & & East Nunavut & 27-May-2013 & $\begin{array}{l}\text { Huynh et al., 2014; Present } \\
\text { study }\end{array}$ \\
\hline KР659255 & B5 & A1896 & Full & & $\begin{array}{c}\text { West } \\
\text { Nunavut }\end{array}$ & 17-Jun-2013 & $\begin{array}{l}\text { Huynh et al., 2014; Present } \\
\text { study }\end{array}$ \\
\hline JN792894 & B5 & A1896 & Full & & $\begin{array}{c}\text { West } \\
\text { Nunavut }\end{array}$ & 01-Sep-2009 & Kowalec et al., 2013 \\
\hline JN792896 & B5 & A1896 & Full & & $\begin{array}{c}\text { West } \\
\text { Nunavut }\end{array}$ & 01-Sep-2009 & Kowalec et al., 2013 \\
\hline JN792897 & B5 & A1896 & Full & & $\begin{array}{l}\text { West } \\
\text { Nunavut }\end{array}$ & 01-Sep-2009 & Kowalec et al., 2013 \\
\hline JN792900 & B5 & A1896 & Full & & $\begin{array}{c}\text { West } \\
\text { Nunavut }\end{array}$ & 01-Sep-2009 & Kowalec et al., 2013 \\
\hline JN792901 & B5 & A1896 & Full & & $\begin{array}{l}\text { West } \\
\text { Nunavut }\end{array}$ & 01-Sep-2009 & Kowalec et al., 2013 \\
\hline DQ463795 & B5 & A1896 & Full & & $\begin{array}{c}\text { West } \\
\text { Nunavut }\end{array}$ & 05-Apr-2004 & Osiowy et al., 2006 \\
\hline DQ463796 & B5 & A1896 & Full & & $\begin{array}{c}\text { West } \\
\text { Nunavut }\end{array}$ & 05-Apr-2004 & Osiowy et al., 2006 \\
\hline DQ463799 & B5 & A1896 & Full & & $\begin{array}{c}\text { West } \\
\text { Nunavut }\end{array}$ & 05-Apr-2004 & Osiowy et al., 2006 \\
\hline DQ463802 & B5 & A1896 & Full & & $\begin{array}{c}\text { West } \\
\text { Nunavut }\end{array}$ & 05-Apr-2004 & Osiowy et al., 2006 \\
\hline \multicolumn{8}{|c|}{ GREENLAND } \\
\hline КР659230 & B5 & A1896 & Partial & $\begin{array}{l}1-20 ; 211-881 \\
\quad 1618-3215\end{array}$ & $\begin{array}{c}\text { East } \\
\text { Greenland }\end{array}$ & 01-Nov-1998 & Present study \\
\hline КР659231 & B5 & A1896 & Partial & $\begin{array}{l}159-881 ; 1362- \\
3184\end{array}$ & $\begin{array}{l}\text { East } \\
\text { Greenland }\end{array}$ & 01-Nov-1998 & Present study \\
\hline КР659232 & B5 & A1896 & Partial & $\begin{array}{l}158-880 ; 1362- \\
3183\end{array}$ & $\begin{array}{c}\text { East } \\
\text { Greenland }\end{array}$ & 01-Nov-1998 & Present study \\
\hline КР659233 & B5 & A1896 & Partial & $\begin{array}{l}159-880 ; 1628- \\
3183\end{array}$ & $\begin{array}{l}\text { East } \\
\text { Greenland }\end{array}$ & 01-Nov-1998 & Present study \\
\hline AB287320 & B5 & A1896 & Full & & $\begin{array}{l}\text { West } \\
\text { Greenland }\end{array}$ & 01-Jan-1998 & Sakamoto et al., 2007 \\
\hline AB287321 & B5 & A1896 & Full & & $\begin{array}{l}\text { West } \\
\text { Greenland }\end{array}$ & 01-Jan-1998 & Sakamoto et al., 2007 \\
\hline AB287322 & B5 & A1896 & Full & & $\begin{array}{l}\text { West } \\
\text { Greenland }\end{array}$ & 01-Aug-2004 & Sakamoto et al., 2007 \\
\hline AB287323 & B5 & A1896 & Full & & $\begin{array}{l}\text { West } \\
\text { Greenland }\end{array}$ & 01-Jan-1998 & Sakamoto et al., 2007 \\
\hline AB287324 & B5 & A1896 & Full & & $\begin{array}{l}\text { West } \\
\text { Greenland }\end{array}$ & 01-Aug-2004 & Sakamoto et al., 2007 \\
\hline AB287325 & B5 & A1896 & Full & & $\begin{array}{l}\text { West } \\
\text { Greenland }\end{array}$ & 01-Aug-2004 & Sakamoto et al., 2007 \\
\hline \multicolumn{8}{|c|}{ ASIA } \\
\hline AB010289 & B1 & G1896 & Full & & Japan & 01-Jan-1993 & Koseki et al., 1999 \\
\hline AB010290 & $\mathrm{B} 1$ & A1896 & Full & & Japan & 01-Jan-1993 & Koseki et al., 1999 \\
\hline AB010291 & $\mathrm{B} 1$ & A1896 & Full & & Japan & 01-Jan-1993 & Koseki et al., 1999 \\
\hline AB010292 & B1 & A1896 & Full & & Japan & 01-Jan-1993 & Koseki et al., 1999 \\
\hline
\end{tabular}




\begin{tabular}{ccccccc} 
AB073838 & B1 & A1896 & Full & Japan & 01-Jan-2001 & Sugauchi et al., 2002 \\
D23677 & B1 & G1896 & Full & Japan & 01-Jan-2000 & Horikita et al., 1994 \\
D23678 & B1 & A1896 & Full & Japan & 01-Jan-2000 & Horikita et al., 1994 \\
D23679 & B1 & A1896 & Full & Japan & 01-Jan-2000 & Horikita et al., 1994 \\
AB287326 & B1 & A1896 & Full & Japan & 01-Jan-2006 & Sakamoto et al., 2007 \\
AB287327 & B1 & A1896 & Full & Japan & 01-Jan-2006 & Sakamoto et al., 2007 \\
AB602818 & B1 & G1896 & Full & Japan & 01-Aug-2005 & Inoue et al., 2011 \\
FJ386584 & B2 & G1896 & Full & China & 21-Feb-2008 & Xu et al., 2011 \\
FJ386600 & B2 & G1896 & Full & China & 03-Mar-2008 & Xu et al., 2011 \\
FJ386636 & B2 & G1896 & Full & China & 22-Feb-2008 & Xu et al., 2011 \\
GQ924653 & B2 & G1896 & Full & Malaysia & 27-Jan-2007 & Meldal et al, 2011 \\
\hline
\end{tabular}

*Nucleotide numbering based on GenBank accession no. DQ463795 (3215nt in length) 